\title{
Peptic ulcer, gastric secretion, and body build
}

\author{
J. H. BARON ${ }^{1}$ \\ From the Institute of Clinical Research, \\ Middlesex Hospital Medical School, London
}

EDITORIAL SYNOPSIS The long-held view that body build could be related to gastric secretion and a diathesis to the development of gastric or duodenal ulcer seems to have been disproved by this careful study, in which the peak acid output of the augmented histamine test could not be correlated with body weight, surface area, or linearity in a group of normal and ulcer subjects. Re-examination of data collected by Lee Lander and Maclagan in 1934 fails to show any relation between gastric secretion and bodily build in normal subjects.

In the course of studies of gastric secretion with an augmented histamine test the opportunity was taken to determine whether the body build of patients with gastric or duodenal ulcer differed from normal and whether there was any correlation between gastric acid output and body build.

\section{METHODS}

The criteria of selection for the 20 male and 20 female subjects without dyspepsia, the 20 male and 20 female patients with gastric ulcer, and the 40 male and 20 female patients with duodenal ulcer have been described

'Leverhulme research scholar elsewhere (Baron, 1963a and b). The height and weight of each subject were measured at the time of the augmented histamine test. From these measurements the surface area and linearity (the ponderal index, height in inches/ $3 \sqrt{\text { weight }}$ in pounds) were calculated. The technique of measuring peak acid output has been described elsewhere (Baron, 1963a).

\section{RESULTS}

It will be seen from Table I that, although in all the subjects men are significantly taller, heavier, and have a larger surface area than women, the differences between the sexes in linearity are insig-

\section{TABLE I}

HEIGHT, WEIGHT, SURFACE AREA, AND PONDERAL INDEX OF SUBJECTS WITHOUT DYSPEPSIA, WITH GASTRIC ULCER, OR WITH DUODENAL ULCER, TOGETHER WITH THE SIGNIFICANCE OF THE DIFFERENCES BETWEEN SEXES AND OF PATIENTS WITH ULCER FROM NORMAL

\begin{tabular}{|c|c|c|c|c|}
\hline & $\begin{array}{l}\text { Height (in.) } \\
\text { Mean } \pm \text { S.E. }\end{array}$ & $\begin{array}{l}\text { Weight (kg.) } \\
\text { Mean } \pm \text { S.E. }\end{array}$ & $\begin{array}{l}\text { Surface Area (sq. m.) } \\
\text { Mean } \pm \text { S.E. }\end{array}$ & $\begin{array}{l}\text { Ponderal Index } \\
\text { Mean } \pm \text { S.E. }\end{array}$ \\
\hline $\begin{array}{l}\text { Normal } \\
\text { Male } \\
\text { Female }\end{array}$ & $\left.\begin{array}{l}68.95 \pm 0.57 \\
64.09 \pm 0.69\end{array}\right\}<0.001$ & $\left.\begin{array}{r}67.9 \pm 1.97 \\
58.40 \pm 1.79\end{array}\right\}<0.001$ & $\left.\begin{array}{c}1.81 \pm 0.03 \\
1.61 \pm 0.03\end{array}\right\}<0.001$ & $\left.\begin{array}{l}13.00 \pm 0.12 \\
12.76 \pm 0.11\end{array}\right\}>0.1$ \\
\hline $\begin{array}{l}\text { Gastric ulcer } \\
\text { Male } \\
\text { Female }\end{array}$ & $\left.\begin{array}{l}68.50 \pm 0.60 \\
62.65 \pm 0.53\end{array}\right\}<0.001$ & $\left.\begin{array}{l}62.85 \pm 1.97 \\
49.55 \pm 1.92\end{array}\right\}<0.001$ & $\left.\begin{array}{l}1.74 \pm 0.03 \\
1.48 \pm 0.03\end{array}\right\}<0.001$ & $\left.\begin{array}{l}13.27 \pm 0.13 \\
13.12 \pm 0.15\end{array}\right\}>0.4$ \\
\hline $\begin{array}{l}\text { Duodenal ulcer } \\
\text { Male } \\
\text { Female }\end{array}$ & $\left.\begin{array}{l}68.21 \pm 0.40 \\
63.94 \pm 0.81\end{array}\right\}<0.001$ & $\left.\begin{array}{l}70.00 \pm 1.87 \\
61.30 \pm 2.87\end{array}\right\}<0.02$ & $\left.\begin{array}{l}1.81 \pm 0.03 \\
1.63 \pm 0.04\end{array}\right\}<0.001$ & $\left.\begin{array}{l}12.80 \pm 0.13 \\
12.59 \pm 0.19\end{array}\right\}>0.4$ \\
\hline $\begin{array}{l}\text { Significance, } P, \text { of } \\
\text { difference from } \\
\text { normal } \\
\text { Gastric ulcer } \\
\text { Male } \\
\text { Female }\end{array}$ & $\begin{array}{l}>0.5 \\
>0.1\end{array}$ & $0.001 \stackrel{>0.1}{<P<0.01}$ & $\begin{array}{c}>0.1 \\
0.001<\mathrm{P}<0.01\end{array}$ & $\begin{array}{c}>0.1 \\
0.05<\mathrm{P}<0.1\end{array}$ \\
\hline $\begin{array}{l}\text { Duodenal ulcer } \\
\text { Male } \\
\text { Female }\end{array}$ & $\begin{array}{l}>0.2 \\
>0.8\end{array}$ & $\begin{array}{l}>0.4 \\
>0.4\end{array}$ & $\begin{array}{l}>0.9 \\
>0.7\end{array}$ & $\begin{array}{l}>0.2 \\
>0.4\end{array}$ \\
\hline
\end{tabular}


TABLE II

CORRELATION WITH PEAK ACID OUTPUT OF HEIGHT, WEIGHT, SURFACE AREA, AND PONDERAL INDEX IN MALE AND FEMALE SUBJECTS WITHOUT DYSPEPSIA, WITH GASTRIC ULCER, AND WITH DUODENAL ULCER

\begin{tabular}{|c|c|c|c|c|c|c|c|c|}
\hline & \multicolumn{2}{|l|}{ Height } & \multicolumn{2}{|l|}{ Weight } & \multicolumn{2}{|c|}{ Surface Area } & \multicolumn{2}{|c|}{ Ponderal Index } \\
\hline & $r$ & $P$ & $r$ & $P$ & $r$ & $P$ & $r$ & $P$ \\
\hline $\begin{array}{l}\text { Normal } \\
\text { Male } \\
\text { Female }\end{array}$ & $\begin{array}{r}+0.449 \\
+0.310\end{array}$ & $\begin{array}{l}<0.05 \\
>0.1\end{array}$ & $\begin{array}{l}+0.110 \\
+0.451\end{array}$ & $\begin{array}{l}>0.1 \\
<0.05\end{array}$ & $\begin{array}{l}+0.251 \\
+0.427\end{array}$ & $\begin{array}{l}>0.1 \\
<0.1\end{array}$ & $\begin{array}{l}+0.291 \\
-0.220\end{array}$ & $\begin{array}{l}>0.1 \\
>0.1\end{array}$ \\
\hline $\begin{array}{l}\text { Gastric ulcer } \\
\text { Male } \\
\text { Female }\end{array}$ & $\begin{array}{l}+0.190 \\
+0.123\end{array}$ & $\begin{array}{l}>0.1 \\
>0.1\end{array}$ & $\begin{array}{l}+0.023 \\
-0.214\end{array}$ & $\begin{array}{l}>0.1 \\
>0.1\end{array}$ & $\begin{array}{l}+0.101 \\
+0.112\end{array}$ & $\begin{array}{l}>0.1 \\
>0.1\end{array}$ & $\begin{array}{r}+0.207 \\
-0.173\end{array}$ & $\begin{array}{l}>0.1 \\
>0.1\end{array}$ \\
\hline $\begin{array}{l}\text { Duodenal ulcer } \\
\text { Male } \\
\text { Female }\end{array}$ & $\begin{array}{r}-0.128 \\
+0.140\end{array}$ & $\begin{array}{l}>0.1 \\
>0.1\end{array}$ & $\begin{array}{l}+0.073 \\
+0.228\end{array}$ & $\begin{array}{l}>0.1 \\
>0.1\end{array}$ & $\begin{array}{r}-0.006 \\
+0.238\end{array}$ & $\begin{array}{l}>0.1 \\
>0.1\end{array}$ & $\begin{array}{l}-0.150 \\
-0.175\end{array}$ & $\begin{array}{l}>0.1 \\
>0.1\end{array}$ \\
\hline
\end{tabular}

The values given are the correlation coefficient, $r$, and the significance, $P$, of the difference of $r$ from zero.

nificant. The bodily habitus of patients with duodenal ulcer or male patients with gastric ulcer did not differ significantly from normal. Female patients with gastric ulcer were significantly lighter than normal with a smaller surface area and greater linearity.

It will be seen from Table II that there were no significant correlations in patients with gastric or duodenal ulcer between peak acid output of the stomach and any of the four measurements of body shape. In normal subjects there were correlations of possible significance between peak acid output and height in men $(P<0.05)$, and between peak acid output and weight $(P<0.05)$ and surface area $(0.05<\mathbf{P}<0.1)$ in women.

With the authors' permission, an examination was made of the unpublished results obtained during a study of the acid output of 91 male medical students without dyspepsia (Lee Lander and Maclagan, 1934). Table III shows that in this data there were no significant correlations between any of the four measurements of body habitus and acid output. It should be noted that the acid output of these subjects was not maximal, as were those to the augmented histamine

\section{TABLE III}

CORRELATION $(r)$ OF HEIGHT, WEIGHT, SURFACE AREA, AND PONLIERAL INDEX WITH ACID OUTPUT IN 91 MEDICAL STUDENTS OF LEE LANDER AND MACLAGAN (1934)

\begin{tabular}{lcc} 
Measurement & Mean Value & $\begin{array}{c}\text { Correlation with } \\
\text { Acid Output }\end{array}$ \\
\hline Height (in.) & 69.8 & -0.0314 \\
Weight (kg.) & 66.7 & -0.0433 \\
Surface area (sq. metres) & 1.81 & -0.0575 \\
Ponderal index $\left(\frac{\text { Height }}{\sqrt[3]{ } \text { Weight }}\right)$ & 13.22 & -0.0167
\end{tabular}

test, $0.04 \mathrm{mg} . / \mathrm{kg}$. histamine acid phosphate, (Kay, 1953) but submaximal, measured as the free acid output in the hour following the injection of 0.01 $\mathrm{mg} . / \mathrm{kg}$. histamine.

\section{DISCUSSION}

This admittedly small series of patients provides no support for the hypothesis that the body build of patients with duodenal ulcer is different from normal. The finding that women with gastric ulcer have a smaller surface area and are more linear can be related to their being significantly lighter than the normal women. Their mean index of observed to age-adjusted standard weight (Kemsley, Billewicz, and Thomson, 1962) is $81 \%$ (S.E. 3.7), that is, significantly underweight $(\mathrm{P}<0.001)$. For comparison the control hospital patients used as 'normal' subjects had a mean index of $98 \%$ (S.E. 1.9) and were not significantly different from standard weight $(P>0 \cdot 2)$. It seems likely that women with gastric ulcer lose weight because of their disease rather than that gastric ulcer is more likely to occur in the underweight, for although the standardized mortality ratio of ulcers of the stomach increases from social class I (professional) to social class $\mathbf{V}$ (unskilled) there is no significant social class difference in the relation of weight to height (Kemsley et al., 1962).

In patients with gastric or duodenal ulcer there was no correlation between maximum acid output and body build. It is difficult to explain the results in normal subjects where the correlations for the same physical characteristics differ in men and women. The correlation between peak acid output and body weight in women could be used to support Card's suggestion that the smaller acid output (and parietal cell mass) of women may be simply due to 
their lower body weight or smaller lean body mass. If this hypothesis were correct one would expect there to be a similar correlation in the men of this series, which was not found; nor could Booth, Hunt, Miles, and Murray (1957) find any correlation between body weight and the secretion of pepsin, acid, or chloride either in men or in women in response to a standard meal.

\section{SUMMARY}

The mean weight, surface area, and linearity of 20 women with gastric ulcer were significantly less than in 20 normal women. The height, weight, surface area, and linearity of 20 men with gastric ulcer and 40 men and 20 women with duodenal ulcer were not significantly different from those of 40 normal subjects.

In the patients with gastric ulcer or duodenal ulcer there was no significant correlation between body build and peak acid output as measured by an augmented histamine test. Some correlations of doubtful significance were found in normal subjects in this study but none were found in 91 male students studied here in 1934.
In this series there was no evidence of an association between gastric or duodenal ulcer and body build, nor of an association between gastric secretion and body build.

I wish to thank Dr. G. D. Hadley for his encouragement and advice, and he and the other consultants of the Middlesex Hospital for permission to study their patients, as well as the Clinical Research Committee for facilities in the Institute of Clinical Research. I am indebted to Professor N. F. Maclagan and Dr. Lee Lander for access to their data.

\section{REFERENCES}

Baron, J. H. (1963a). Studies of basal and peak acid output with an augmented histamine test. Gut, 4, 136-144.

- (1963b). An assessment of the augmented histamine test in the diagnosis of peptic ulcer. Ibid., 4, 243-253.

Booth, M., Hunt, J. N., Miles, J. M., and Murray, F. A. (1957) Comparison of gastric emptying and secretion in men and women with reference to prevalence of duodenal ulcer in each sex. Lancet, 1, 657-659.

Kay, A. W. (1953). Effect of large doses of histamine on gastric secretion of $\mathbf{H C l}$. Brit. med. J., 2, 77-80.

Kemsley, W. F. F., Billewicz, W. Z., and Thomson, A. M. (1962). A new weight-for-height standard based on British anthropometric data. Brit. J. prev. soc. Med., 16, 189-195.

Lander, F. P. L., and Maclagan, N. F. (1934). One hundred histamine test meals on normal students. Lancet, 2, 1210-1213. 